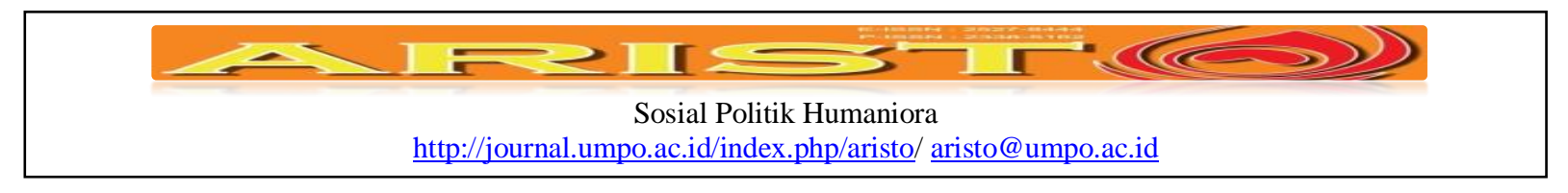

\title{
Tata Kelola Olah Raga dengan Figur Politik dari Militer: Studi Kasus Pemerintah Indonesia dalam Konteks Sepak Bola
}

Andika Sanjaya ${ }^{1}$, Hardi Alunaza SD ${ }^{2}$, Achmad Bayu Chandra Buwono ${ }^{3}$, Nining Nadya Rukmana Sari $^{4}$

${ }^{1}$ Program Studi Ilmu Komunikasi, FISIP, Universitas Lambung Mangkurat Banjarmasin.

${ }^{2}$ Program Studi Ilmu Hubungan Internasional, FISIP, Universitas Tanjungpura Pontianak.

${ }^{3}$ Program Studi Ilmu Komunikasi, FISIP, Universitas Lambung Mangkurat Banjarmasin.

${ }^{4}$ Program Studi Ilmu Komunikasi, FISIP, Universitas Lambung Mangkurat Banjarmasin. andikasanjaya@student.undip.ac.id, hardialunaza@gmail.com, Bayuchandra459@gmail.com, nining_nadya@yahoo.com

\begin{abstract}
Indonesian football turns to be a "colosseum" of yearly political conflict among political "gladiators". The government aware that according to the history, there is a closeness between football and politics. The government also aware that football can be used as a soft power to stay existed on the international stage. The problem is, the international football federation prohibit the intervention of the government and give a punishment in the shape of suspension for the violators. This paper used a case study method to explain the phenomenon. The government choose using a political figure to indirectly resolute the conflict and govern the football. The military-political figure tends to have suitable characteristics to help the government. However, the political figure has a personal political ambition. It is reasonable in Indonesia.
\end{abstract}

Keyword: Sports governance, political figure, public spaces, conflict resolution, political communication.

\begin{abstract}
Abstrak
Sepak bola Indonesia menjadi "koloseum" konflik politik menahun bagi para "gladiator" politik. Pemerintah menyadari bahwa menurut sejarah, ada kedekatan antara sepak bola dan politik. Pemerintah juga menyadari sepak bola dapat digunakan sebagai kekuatan halus untuk eksis di panggung internasional. Permasalahannya, federasi sepak bola internasional melarang intervensi pemerintah dan memberi hukuman berupa pembekuan bagi negara pelanggar. Paper ini menggunakan metode studi kasus untuk menjelaskan fenomena yang terjadi. Pemerintah memilih menggunakan figur politik untuk secara tidak langsung menyelesaikan konflik dan mengelola sepak bola. Figur politik militer memiliki karakteristik untuk memuluskan rencana pemerintah. Meskipun demikian, figur politik juga memiliki ambisi politik pribadi. Hal itu wajar di Indonesia.
\end{abstract}

Keyword: Tata kelola olahraga, figur politik, ruang publik, resolusi konflik, komunikasi politik.

\begin{tabular}{|ll|}
\hline Submite & $:$ 20 Desember 2017 \\
Review & $:$ 10 Januari 2018 \\
Accepted & $:$ 30 Juni 2018 \\
Surel Corespondensi & $:$ jovani.audra@gmail.com \\
\hline
\end{tabular}

\section{Pendahuluan}

Pada panggung internasional, Fédération Internationale de Football Association (FIFA) berlaku sebagai TNC (transnational corporations) pemasaran sepak bola global sekaligus NGO (non-governmental organization). Posisi FIFA sebagai aktor non-negara yang memiliki 


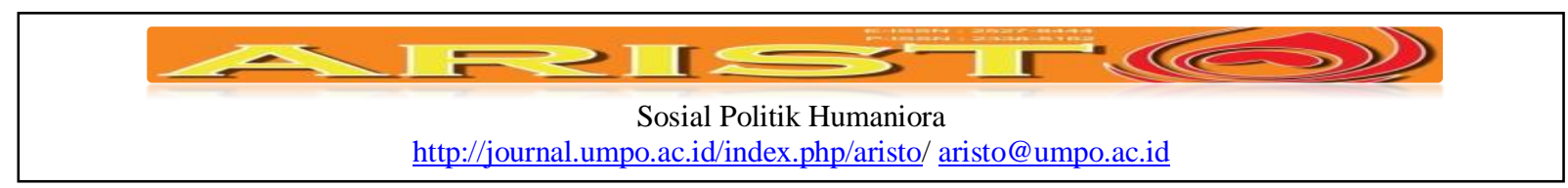

kekuasaan dalam politik. Kasus dominasi politik FIFA menjadi contoh bagaimana sudut pandang neo-liberal berlaku di ranah global. Sebagai TNC, FIFA memiliki TPR (transnational private regulation), semacam regulasi yang memungkinkan penetapan regulasi dan standar global terkait suatu isu. Batas negara tidak berlaku dalam konteks TNC (Meier \& Garcia, 2015). Statuta FIFA merupakan wujud TPR dari FIFA. Statuta FIFA merupakan Lex Sportiva yang berfungsi untuk menyelesaikan konflik dualisme dari sepak bola suatu negara (Aruan, Sirait, Leviza, 2014).

Pemerintahan FIFA merujuk pada hierarkis kekuasaan vertikal. FIFA membawahi kompetisi regional, kompetisi nasional, klub, dan pemain. Pengaruh FIFA sampai ke pemain sebagai individu (Amara et al, 2005). Pada tahun 2005, FIFA semakin menunjukkan dominasi melalui kebjakan "suspension" (pembekuan). FIFA menegasi pihak-pihak diluar mereka untuk melakukan intervensi. Sasaran utama FIFA tidak lain adalah pemerintahan negara. Intervensi pemerintah merupakan alasan paling umum suspensi FIFA. Antara 2004-2013, sepak bola 17 negara merasakan sanksi FIFA karena intervensi pemerintah.Guatemala, Kenya, Macau, Yaman, Yunani, Iran, Kuwait, Albania, Madagascar, Chad, Iraq, Ethipia, Peru, Brunei Darussalam, El Salvador, Nigeria, dan Kamerun adalah negara-negara yang terkena sanksi tersebut (Meier \& Garcia, 2015).

Di dalam ekosistem sepak bola suatu negara, terdapat banyak stakeholder (pemangku kepentingan) yang terlibat. Selain FIFA dan pemerintahan negara, ada pengaruh juga dari pemerintah kota, federasi regional, suporter, agen, lembaga penyiaran terrestrial, lembaga penyiaran satelit, klub kecil, klub semi-major, klub G14, dan FIFPRO selaku lembaga yang mengurusi pemainPemerintah bukan satu-satunya pemangku kepentingan dalam sepak bola. Dari semua pemangku kepentingan, FIFA muncul sebagai kekuatan terkuat yang dapat mengatur semuanya (Amara et al, 2005). Pemerintah berkepentingan untuk memajukan sepak bola. Sebagai olahraga rakyat, sepak bola mampu menjadi hiburan sekaligus menjadi pendongkrak ekonomi negara. Sepak bola juga dapat menjadi soft power bagi suatu negara (Santosa, 2017).

Eksistensi di dunia internasional menjadi fokus pemerintah Indonesia. Gerakan tersebut dimulai khususnya sejak era Presiden Susilo Bambang Yudhoyono (SBY). Keaktifan dalam dunia internasional menjadi salah satu indikator kebangkitan Indonesia. Sepak bola adalah salah satu jalan bagi pemerintah untuk lebih aktif di dunia internasional. Selain itu, konflik yang terjadi di dalam negara harus segera diselesaikan, apalagi konflik yang sudah mengganggu stabilitas nasional (Santosa, 2017). 


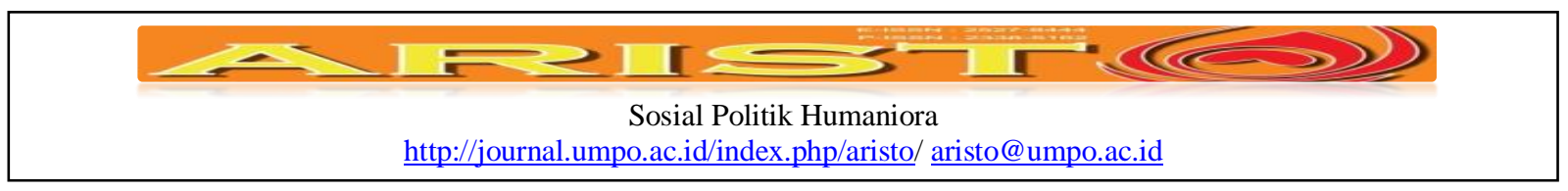

Belajar dari Republik Rakyat Tiongkok (RRT), negara tersebut menggunakan sepak bola untuk visi negara superpower. Sedangkan, sepak bola Asia saat ini mulai memperoleh tempat di dalam percaturan sepak bola internasional. Oleh karena itu, jika sepak bola Indonesia mengalami konflik berkepanjangan, maka sesegera mungkin harus diselesaikan (Santosa, 2017).

Sepak bola Indonesia memiliki karakteristik unik. Dari sejak sebelum kemerdekaan, sepak bola Indonesia selalu digunakan untuk kepentingan politik. Archetti (2005) menentang bahwa sepak bola bukan tentang politik, namun, kenyataannya, sepak bola Indonesia sangat erat kaitannya dengan politik. Aktor-aktor politik dan partai politik mengintervensi jalannya persepakbolaan nasional (Colombijn, 2000). Pemerintah Indonesia sadar telah terjadi konflik bertahun-tahun di dunia sepak bola nasional. Konflik sepak bola berkaitan dengan politik. Oleh karena itu, pemerintah berkeinginan untuk menyelesaikannya. Namun, ego kedua kubu yang berkonflik sangat besar, pemerintah memerlukan cara khusus yang relatif aman di bawah pengawasan FIFA (Ariyanto, 2013).

Secara khusus, Colombijn menyayangkan bahwa sepak bola Indonesia, khususnya terkait politik, kurang menarik minat kaum akademisi. Bidang tersebut hanya dikaji oleh jurnalis. Oleh karena itu, riset terkait politik sepak bola seharusnya diperbanyak. Colombijn dan Santosa mempelajari politik sepak bola berkonteks Indonesia. Bowen, Amara, dan kolega, Archetti, Meier \& Garcia, mempelajari politik sepak bola berkonteks internasional.

Pengamatan terhadap riset-riset sebelumnya menghasilkan kesimpulan bahwa belum ada yang secara rinci membahas peran pemerintah dan figur politik kalangan militer dalam sports governance (tata kelola olahraga), khususnya di Indonesia. Pertanyaan penelitian ini adalah bagaimana tata kelola pemerintah Indonesia dalam olahraga. Tulisan ini mengidentifikasi peran pemerintah dan figur politik dalam mengelola olahraga. Tulisan ini terbagi menjadi empat poin penting dalam menjelaskan manajemen sepak bola dengan figur politik. Pertama, penjelasan figur politik dan komunikasi politik dalam ruang publik. Kedua, model tata kelola olahraga internasional dan kekuatan halus. Ketiga, model tata kelola olahraga Indonesia dan resolusi konflik. Juga, penglibatan figur politik serta konsekuensi negatif penglibatan figur politik.

\section{Metode}

Pada dasarnya sebuah penelitian adalah kegiatan yang dilakukan untuk mencari jawaban terhadap pertanyaan yang ingin diketahui penulis. Tulisan tentang manajemen sepak bola dengan 


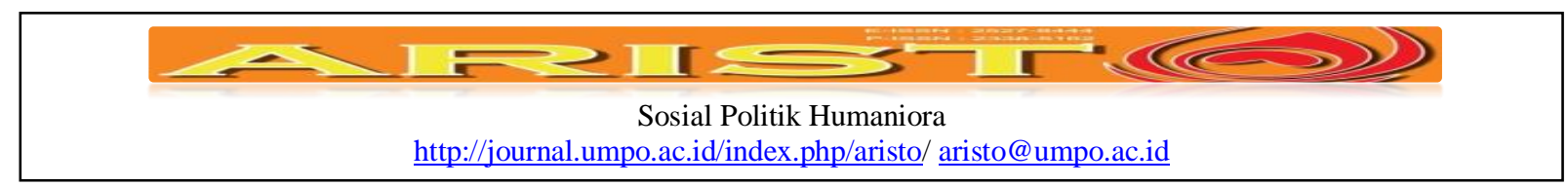

figur politikini termasuk penelitian deskriptif dengan pendekatan kualitatif, di mana penulis berusaha untuk memberikan gambaran atau mendeskripsikan keadaan objek serta permasalahan yang ada. Oleh karena itu, metode deskriptif di sini diharapkan dapat mencapai tujuan penelitian, yaitu menggambarkan secara jelas fakta dan karakteristik objek yang diteliti secara tepat.

Secara khusus, penelitian ini menggunakan metode studi kasus. Studi kasus diperlukan untuk menjawab pertanyaan bagaimana dan mengapa tentang fenomena yang dijadikan tujuan riset. Penelitian studi kasus ini hanya mengambil satu fenomena, yaitu tata kelola olahraga oleh pemerintah Indonesia dengan figur politik. Pemilihan kasus untuk studi kasus dengan dilengkapi alasan. Peneliti menemukan bahwa kecenderungan pemerintah untuk intervensi dengan cara tidak langsung di bawah bayang-bayang ancaman hukuman dari federasi sepak bola internasional menjadi isu menarik (Boue \& Kjaer, 2010).

Penulis menggunakan data sekunder dengan teknik pengumpulan data melalui studi pustaka, buku-buku, jurnal, laporan penelitian, prosiding konferensi, dan data dari situs yang reliabel yang terkait dan mendukung data penelitian ini. Dalam tulisan ini digunakan tiga alur untuk mengambil kesimpulan dari data yang diperoleh dan diamati (Sugiono, 2011).

Metode studi deskriptif kualitatif telah digunakan oleh Colombijn dan Santosa untuk mempelajari politik sepak bola berkonteks Indonesia. Colombijn (2000) menggunakan studi deskriptif kualitatif untuk menganalisis aspek kontinuitas sepak bola Indonesia, peran sepak bola terhadap perubahan sosial, serta peran aktor-aktor politik dalam sepak bola Indonesia. Santosa (2017) menggunakan studi deskriptif kualitatif untuk mempelajari bagaimana negara Republik Rakyat Tiongkok (RRT) mengelola soft power sepak bola untuk menjadi negara superpower. Selain melibatkan pemerintah, pengelolaan juga melibatkan sektor bisnis.

Selain itu, metode studi deskriptif kualitatif juga digunakan oleh Bowen, Amara, dan kolega Archetti, Meier \& Garcia dalam meneliti politik sepak bola dalam konteks internasional. Sesuai dengan riset-riset terdahulu, data diperoleh melalui literatur akademis dan media massa. Bowen menggunakan studi deskriptif kualitatif untuk meneliti peran tentara PBB dalam mengintervensi situasi suatu negara. Meskipun tidak secara langsung berhubungan dengan sepak bola, namun peran tentara dalam penyelesaikan konflik dijelaskan secara rinci dalam riset tersebut.

Amara dan kolega menggunakan studi deskriptif kualitatif untuk memetakan beberapa model intervensi pemerintah dalam sepak bola. Beberapa negara menjadi contoh kasus yang 


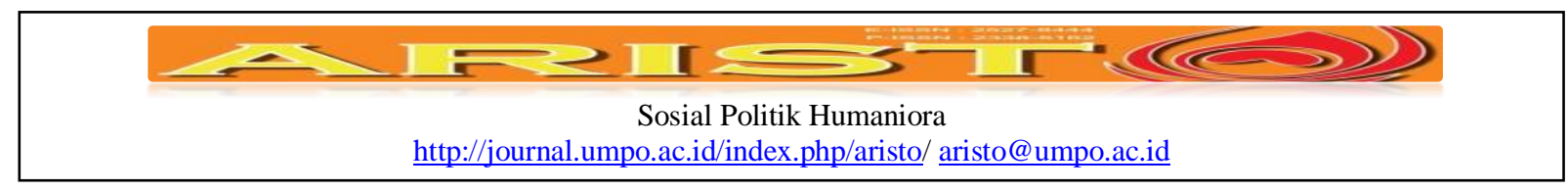

diteliti, secara khusus mewakili karakteristik yang berbeda-beda. Archetti menggunakan studi deskriptif kualitatif untuk mengidentifikasikan kebimbangan moral yang terjadi antara politik dan sepak bola. Konteks yang diambil adalah dalam penyelenggaraan event internasional Piala Dunia di Argentina yang bersamaan dengan kondisi junta militer.

Meier \& Garcia meneliti bagaimana tiga negara berusaha melawan dominasi FIFA sebagai TNC. Namun, pada akhirnya, ketiganya harus menggunakan cara yang direstui FIFA untuk menyelesaikan konflik sepak bola. Dari beberapa riset tersebut, menjadi alasan peneliti menggunakan metode studi deskriptif kualitatif. Pengambilan data dari media massa sebagai pelengkap, karena data primer penelitian politik dan sepak bola berkonteks Indonesia belum banyak tersedia, seperti yang diungkapkan oleh Colombijn.

\section{Hasil danPembahasan}

\section{Figur Politik dan Komunikasi Politik dalam Ruang Publik}

Politisi berusaha meraih tujuan mereka melalui komunikasi politik dalam ruang publik. Politisi berkomunikasi untuk memperoleh apa yang mereka inginkan. Politisi dapat memanfaatkan ruang publik, seperti dijelaskan Habermas, sebagai ruang penghubung antara publik dan pemerintah. Politisi dapat memanfaatkan media massa untuk mendominasi ruang publik. Ketika memperoleh akses kepada ruang publik, politisi dapat mempengaruhi masyarakat selaku calon pemilih (Iqbal, 2016).

Sepak bola merupakan cabang olahraga terpopuler di Indonesia. Sepak bola dianggap sangat menarik untuk dimanfaatkan para politisi. Mereka bisa menggunakan sepak bola untuk memperoleh imej positif, memperoleh pendanaan, dan memperoleh peliputan media yang luas (Dorsey \& Sebastian, 2016). Sepak bola merupakan ruang publik yang dapat dimanfaatkan oleh politisi. Ketika politisi berhasil masuk ke sepak bola, maka mereka secara otomatis memperoleh ruang publik untuk berkampanye. Sepak bola adalah ruang publik yang banyak memperoleh visibilitas, khususnya di Indonesia (Iqbal, 2016).

Politisi di Indonesia bahkan berani menjalankan cara kotor pengaturan skor untuk kepentingan politik. Pengaturan skor merupakan cara yang dilakukan politisi lintas generasi (Colombijn, 2000). Pengaturan skor untuk politik, merupakan cari bagi figur politik untuk memperoleh visibilitas dalam ruang publik. Politisi menggunakan beranekaragam cara untuk mempengaruhi hasil pertandingan tim yang mereka dukung. Ketika tim yang mereka dukung 


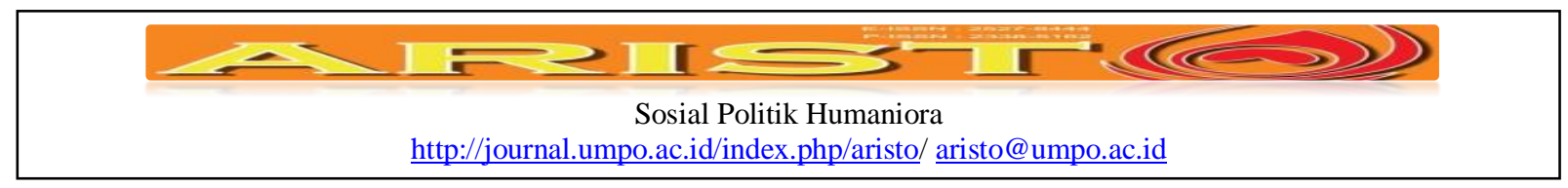

menang, maka politisi secara otomoatis akan lebih sering memperoleh atensi media massa. Atensi media massa, bagi politisi dapat berarti memperoleh ruang publik, sedangkan ruang publik berarti visibilitas (Iqbal, 2016).

Perebutan ruang publik, pada akhirnya menghasilkan konflik politik. Konflik internal dalam federasi sepak bola Indonesia, PSSI, bermula dari perubahan sistem kompetisi Liga Indonesia yang digaungkan ketua umum terpilih pada September 2011, Djohar Arifin Husein.Anggota Komite Eksekutif (exco) PSSI, La Nyalla Mattalitti meminta liga tidak diubah dan kepengurusan lama era ketum Nurdin Halid dimasukkan dalam kepengerusan PSSI yang baru. Djohar menentang tuntutan La Nyalla, dan menjalankan kompetisi dengan format baru bernama Liga Primer Indonesia (LPI). Kompetisi ini memecah exco PSSI menjadi dua kelompok. Dari sinilah, kemudian terjadi dualisme PSSI dan KPSI. KPSI adalah federasi bayangan yang dibuat untuk menentang kebijakan PSSI (Sammy, 2012).

Media massa dapat dimanfaatkan oleh pihak-pihak yang berkonflik untuk mewujudkan tujuan mereka. Konflik dapat dipertajam dan diperjelas dengan adanya media massa. Hiperrealitas yang dibangun media massa, dramatisasi melampau realitas, menjadi ancaman bagi resolusi konflik. Konflik lanjutan akan tersulut melalui provokasi figur politik (Anggoro, 2014).

Sekilas, konflik dualisme sepak bola yang dimulai tahun 2011 tersebut bukan merupakan konflik politik. Kedua disputan punya prinsip masing-masing untuk tetap berkonflik. Namun, pada perjalanannya, kedua ketua federasi Djohar Arifin dan La Nyalla Mattalitti, menjadikan sepak bola sebagai jalan memperoleh visibilitas politik. Djohar mendeklarasikan diri berhasrat mendaftar sebagai calon kepala daerah di Kabupaten Langkat untuk pemilihan umum (pemilu) 2018 (Santama, 2017). La Nyalla juga berkeinginan menjadi calon kepala daerah di Provinsi Jawa Timur untuk pemilu di tahun yang sama (Priyasidarta, 2017). Selain keduanya, mantan ketum PSSI sebelumnya, Nurdin Halid, juga berkeinginan maju sebagai calon kepala daerah di Provinsi Sulawesi Selatan (Wirabhuana, 2017).

Sepak bola merubah masyarakat. Pertarungan sepak bola bergeser dari etnis ke wilayah, hal ini menandakan suatu integrasi karena identitas bergeser pada pembagian wilayah. Dulu sepak bola mempertemukan perlawanan nasionalisme dan kolonialisme. Sekarang, pemimpin memanfaatkan sepak bola untuk mengalahkan rivalnya untuk menumbuhkan sikap kedaerahan dan membuat imej positif (Colombijn, 2000). 


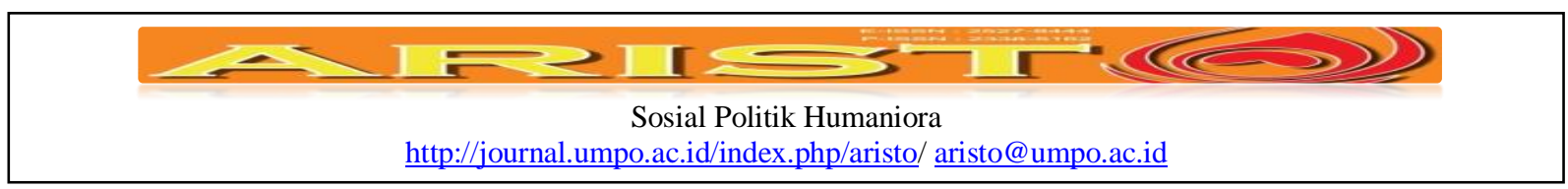

Politisi, ketika muncul di ruang publik, akan mengelola visibilitas (tampilan) secara khusus. Sebagai figur publik, politisi akan menunjukkan nilai-nilai pribadi yang melekat pada mereka. Masyarakat akan menilai imej seorang politisi seperti politisi memposisikan diri mereka di ruang publik. Publik dapat berkomunikasi sekaligus mengamati dimensi simbolis dari politisi. Visibilitas terkait dengan representasi sosial. Politisi dapat memunculkan citra "pahlawan" maupun "orang biasa", atau menonjolkan sifat-sifat khusus. Sifat-sifat humanis yang ditunjukkan politisi di ruang publik dapat berupa kekuatan, kejujuran, dapat dipercaya (Iqbal, 2016).

\section{Model Tata Kelola Olahraga Internasional dan Soft Power}

Tata kelola (governance) merupakan pergeseran dari pemerintahan (government). Perbedaan dari tata kelola dan pemerintahan yaitu pada prosesnya. Pemerintahan bersifat intervensi langsung, sedangkan tata kelola bersifat intervensi tidak langsung. Dominasi FIFA mengharuskan sepak bola dikelola secara tidak langsung, oleh karena itu, pemerintah memerlukan tata kelola yang tepat (Amara et al, 2005).

Tata kelola sepak bola di Indonesia berbeda dengan lima negara yang diteliti oleh Amara dan kolega. Federasi sepak bola Inggris (FA) juga pernah mengalami konflik domestik dalam hal kompetisi seperti di Indonesia, namun berbeda penanganan. Inggris pernah mengalami konflik kompetisi domestik yang saat ini bertransformasi menjadi Premier League (Liga Primer Inggris). Tahun 1985, Manchester United, Liverpool, Everton, Arsenal, dan Spurs bersama-sama mogok dengan tuntutan adanya kompetisi tandingan kecuali tim-tim tersebut memperoleh pemasukan kontrak televisi yang lebih tinggi. Keinginan kelima klub tersebut juga tidak serta merta terwujud. Pada tahun 1961, gaji maksimum dihilangkan. Liga yang sudah terbentuk profesional sejak tahun 1885 tersebut menunjukkan dinamisme menuju atmosfer yang lebih kompetitif. Pada tahun 1965, BBC menayangkan "Match of the Day" dengan bayaran besar untuk klub peserta. Klub menyadari bahwa liga semakin kompetitif, mereka membutuhkan pemasukan yang lebih banyak melalui pengelolaan yang lebih profesional. Klub-klub bernegosiasi dengan stasiun televisi hingga tersepakati pada tahun 1992. Liga Primer Inggris dimulai sejak didukung stasiun televisi BskyB dan BBC. Liga memperoleh kontrak komersial yang tinggi pasca terbentuk Liga Primer Inggris (Amara et al, 2005).

Satu hal yang unik, pada masa tersebut, FIFA cenderung menerima jadi hasil pemberontakan klub Inggris tersebut. Bahkan, bersama Uni Eropa, FIFA mengandemen sistem 


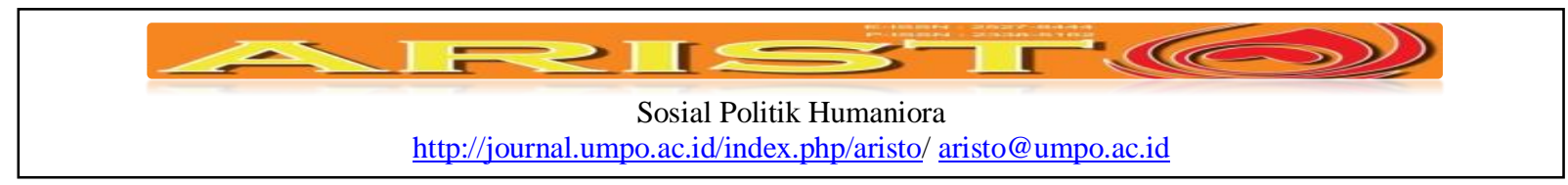

transfer pemain. Pada fase-fase tersebut, dominasi FIFA belum sekuat saat ini, namun hal itu dapat disebabkan konflik dapat selesai tanpa campur tangan pemerintah Inggris. Peran pemerintah, khususnya nasional dan lokal, sangat rendah dalam sepak bola Inggris. Pembentukan Task Force adalah peran pemerintah dalam penyelesaian konflik, namun, lima klub besar dan media menjadi pemangku kebijakan utama. Dari model neo-liberal Inggris tersebut, dapat dijelaskan bahwa konflik bukan merupakan hal yang harus dihindari. Konflik jika dikelola dengan benar, maka akan berdampak pada kondisi yang lebih baik bagi pemangku kebijakan yang terlibat dalam industri sepak bola (Amara et al, 2005). .

Hampir mirip dengan model Inggris, intervensi pemerintah pusat di Jepang juga cukup rendah. Namun, pemerintah lokal memiliki kekuatan yang dominan. Bersama sektor bisnis dan korporat, pemerintah lokal mengelola sepak bola Jepang, termasuk penyediaan fasilitas semisal stadion. Kondisi terbalik terjadi di sepak bola RRT dan Perancis. Peran pemerintah sangat besar, khususnya di RRT. Hampir seluruh kepentingan terkait sepak bola RRT dibatasi oleh pemerintahan negara dan lokal. Di Perancis, peran klub hanya mempengaruhi, tidak dapat menginisiasi konflik terbuka seperti di Inggris. Selain ujung kiri dan kanan dalam bandul tata kelola sepak bola keempat negara (Inggris, Japan, Perancis, dan RRT), ada kondisi yang berada di tengah-tengah. Sepak bola Algeria menjadi contoh kasus yangmana pemerintah memiliki peran intervensi pada taraf sedang. Ada variasi tingkat pengaruh pemerintah dalam pengelolaan sepak bola dari negara-negara tersebut (Amara et al, 2005).

Jika dibandingkan dengan beberapa negara yang telah disebut, pemerintah Indonesia, baik pusat maupun lokal, memiliki niat yang tinggi untuk mengintervensi sepak bola . Konflik di Indonesia banyak dipengaruhi oleh kepentingan politik. Disputan merupakan dua federasi (PSSI dan KPSI) dalam satu negara, keduanya didasari oleh kepentingan politik (Colombijn, 2000; Amara et al, 2005). Intervensi pemerintah dapat berupa kekuatan halus. Negara adalah tentang kekuatan terhadap negara lain. Kekuatan halus ini dimanfaatkan oleh pemerintah untuk mempengaruhi pihak-pihak lain. Kelebihan kekuatan halus ini terletak pada minimnya penggunaan pemaksaan maupun kekerasan (Alunaza\& Sanjaya, 2016).

\section{Model Tata Kelola Olahraga Indonesia dan Resolusi Konflik}

Olahraga merupakan salah satu alat untuk melanggengkan atau menghentikan konfrontasi dan konflik. Olahraga merupakan alat diplomasi yang digunakan oleh negara-negara di dunia. 


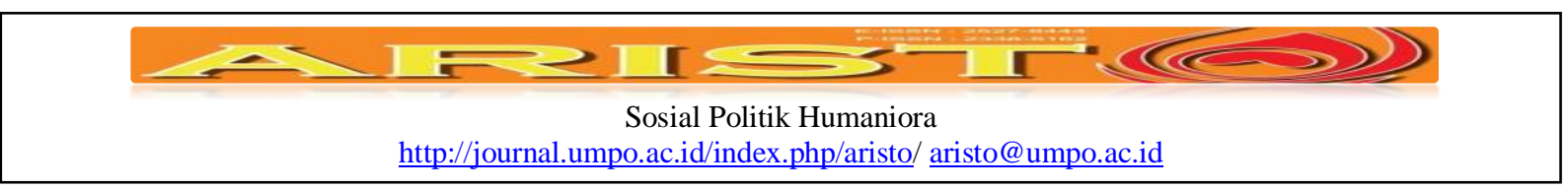

Olahraga juga menjadi alat untuk memperomosikan atau melindungi kepentingan (Bang, 2012).

Sepak bola di Indonesia dapat menjadi sumber konflik (Colombijn, 2000).

Resolusi konflik dapat dijalankan dengan menempatkan figur politik dengan kepemimpinan kuat. Kepemimpinan kuat merupakan faktor utama dalam perundingan perdamaian. Pemimpin yang kuat juga diperlukan dalam menyelesaikan konflik. Sikap dan perilaku pemimpin tersebut penting untuk menyelesaikan konflik (Bağriyanik, 2016).

Figur politik sejak sebelum kemerdekaan terbiasa melakukan intervensi dalam dunia sepak bola Indonesia. Dibandingkan dengan kasus Inggris, dimana konflik dimulai oleh klubklub besar di negara tersebut. Tujuan konflik di sepak bola Inggris cenderung berasaskan bisnis, bukan politik (Colombijn, 2000; Amara et al, 2005). Dalam kondisi konflik politik di Indonesia, FIFA mengancam memberikan sanksi jika konflik tidak diselesaikan (Sammy, 2012).

FIFA menganggap Liga Super Indonesia (LSI), liga yang dikelola KPSI, adalah liga tandingan yangmana orang-orang didalamnya tidak boleh mengikuti agenda FIFA. PSSI diminta FIFA segera menyelesaikan permasalahan ini. Selanjutnya, KONI muncul sebagai penengah dalam rekonsiliasi kedua belah pihak. KPSI tidak bergeming, bahkan mengadakan kongres tandingan. Pada Maret 2012, PSSI mengakui KPSI untuk menghindari ancaman dari FIFA. Kemunculan FIFA ini adalah faktor eksternal yang mempengaruhi politik sepak bola nasional (Sammy, 2012).

Sempat berdamai untuk meredam faktor eksternal dari FIFA, kedua disputan masih berkonflik hingga perwakilan pemerintah turun tangan. Pada tahun 2015, Menteri Pemuda Olahraga (Menpora) Imam Nahrawi turun tangan. Pada 17 April 2015, Menpora menerbitkan Surat Keputusan berisi pembekuan PSSI. Sehari setelahnya, PSSI mengangkat La Nyalla Mattalitti sebagai Ketua Umum PSSI periode 2015-2019. Namun, La Nyalla tidak diakui karena PSSI dalam kondisi beku oleh pemerintah. Selanjutnya, Menpora mengirimkan surat ke FIFA uintuk menjelaskan kronologi konflik dalam PSSI. Wakil Presiden Jusuf Kalla mencoba menengahi kedua belah pihak dengan Pengadilan Tinggi Usaha Negara (PTUN), namun belum terselesaikan. Sekali lagi, intervensi FIFA kembali muncul dengan ancaman sanksi pada tanggal 29 Mei 2015. PSSI menggugat SK Pembekuan ke PTUN, sedangkan Menpora melarang pertandingan ISL melalui kepolisian. Selanjutnya, kompetisi berhenti di tengah jalan, hingga sebagian publik sepak bola memprotes Presiden Joko Widodo untuk menyelesaikan konflik ini. Pemerintah melalui Menpora membentuk Tim Transisi (TT) untuk mengambil alih fungsi PSSI 


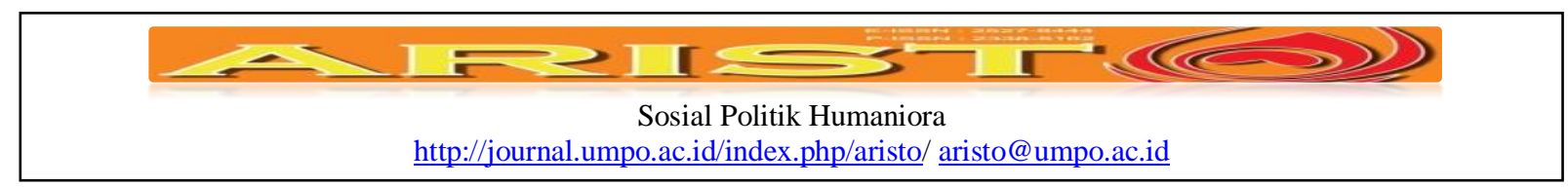

yang beku. Selanjutnya, TT mencoba berkomunikasi dengan FIFA namun ditolak. FIFA justru meminta PSSI mencabut SK Pembekuan PSSI sebelum tanggal 29 Mei 2015 (Christian, 2015).

Selanjutnya, karena konflik belum selesai, FIFA memberikan sanksi kepada Indonesia pada tanggal 30 Mei 2015. Indonesia tidak dapat mengirimkan wakil tim nasional maupun klub ke pertandingan tingkat internasional yang dibawah FIFA. Karena mengagnggap campur tangan pemerintah dalam PSSI cukup besar, FIFA mencantumkan syarat pencabutan sanksi. FIFA mensyaratkan PSSI harus bebas dari intervensi pemerintah. Setahun terkena sanksi, FIFA mencabut sanksi terhadap Indonesia pada tanggal 13 Mei 2016, hal ini dilakukan setelah Menpora mencabut sanksi pembekuan terhadap PSSI (Susanto, 2016).

Dengan pemberian sanksi ini, sebagai faktor eksternal FIFA memegang peran penting dalam mempengaruhi kebijakan politik dalam negeri. Pemerintah juga melakukan aktivitas yang dilarang oleh FIFA sendiri, yaitu mengintervensi PSSI. Sebagai TNC yang memiliki TPR, FIFA menggunakan regulasi untuk menundukkan pemerintah. FIFA bahkan dapat memaksa pemerintah untuk memfasilitasi resolusi konflik. Posisi tawar FIFA sangatlah kuat, karena FIFA adalah satu-satunya jalur partisipasi sepak bola dunia (Meier \& Garcia, 2015).

Statuta FIFA berfungsi sebagai Lex Sportiva dalam komunitas internasional. Lex Sportiva adalah hukum transnasional yang dapat digunakan untuk menghukum stakeholder sepak bola. Hukum bersifat self-regulatory, yang artinya dirumuskan secara sepihak oleh FIFA namun bersifat mengikat. Pemerintah menyelesaikan sengketa dengan membimbing dan memfasiltiasi berpegangan dengan instruksi FIFA. Hal ini akhirnya dianggap bukan bentuk intervensi. Negara sebaiknya hanya turun tangan, bukan campur tangan, secara strategis, terbatas, dan fokus sesuai dengan kapasitas dan kompetensinya (Aruan, Sirait, Leviza, 2014).

Jika menentang, maka industri sepak bola akan disingkirkan dari panggung internasional. Selain itu, jika memperoleh sanksi, subsidi FIFA terhadap suatu negara akan dicabut, begitupula perlindungan para pemain. Jika hal ini terjadi, maka banyak sekali pemangku kebijakan yang terkena imbas dari sanksi FIFA. Oleh karena itu, pemerintah menyadari bahwa intervensi secara langsung bukan merupakan solusi yang tepat (Meier \& Garcia, 2015).

\section{Penglibatan Figur Politik dari Tentara}

Dengan adanya sanksi FIFA, pemerintah Indonesia melibatkan figur politik untuk mengintervensi PSSI. Jika sebelumnya menggunakan SK Pembekuan, saat ini pemerintah 


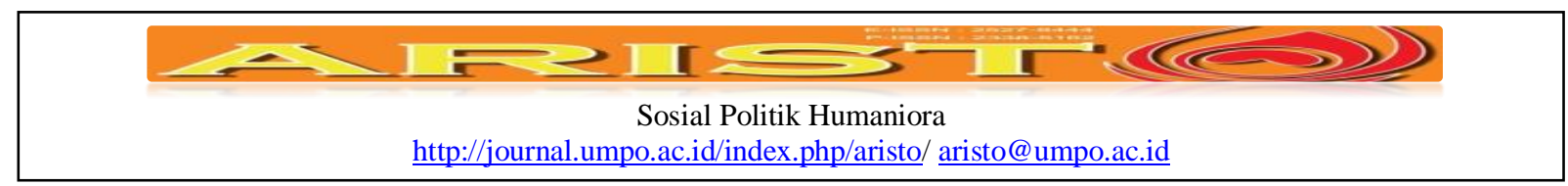

menggunakan figur politik yang diinjeksikan ke dalam tubuh PSSI. Pengaruh pemerintah Indonesia diarahkan untuk pemenangan Edy Rahmayadi untuk Ketua Umum PSSI yang baru. Pada tanggal 10 November 2016, PSSI resmi mengangkat Edy Rahmayadi. Edy adalah figur dalam militer dengan jabatan Pangkostrad. Edy melengkapi deretan ketua umum PSSI dari militer, setelah Ali Sadikin, Maulwi Saelan, Kardono, dan Agum Gumelar. Ketua umum dengan latar belakang militer dianggap sebagai pribadi yang teguh pendirian, tegas, dan tepat untuk meresolusi konflik PSSI (Pandit Football, 2016).

Peran tentara dalam resolusi konflik dapat dipelajari dari konflik antara pemerintah Indonesia dengan Gerakan Aceh Merdeka (GAM). Konflik pemerintah Indonesia dan GAM dimulai sejak era kepemimpinan Presiden Soeharto pada tahun 1976. Presiden dari kalangan militer, Soeharto, memulai konflik dengan GAM setelah deklarasi sepihak mereka untuk memerdekakan Aceh. Konflik tetap berjalan meskipun sudah beberapa kali berganti presiden. Konflik berhenti pada tahun 2005 di era kepemimpinan Susilo Bambang Yudhoyono (SBY) (Bağriyanik, 2016).

Uniknya, penelitian Bağriyanik (2016) membandingkan resolusi konflik yang terjadi di dua negara. Pemerintah Indonesia berkonflik dengan GAM, sedangkan Pemerintah Turki dengan Partiya Karkerên Kurdistanê (PKK), gerakan suku Kurdi. Pemerintah Indonesia berhasil menghentikan konflik menahun, sedangkan Pemerintah Turki gagal. Perbedaannya adalah kepemimpinan militer yang tepat.

SBY menolak untuk melanjutkan konfrontasi dengan GAM, namun memilih jalur negosiasi. Bahkan, SBY memberhentikan Panglima TNI saat itu. Ryamizard Ryacudu. Posisi ini menunjukkan kepada disputan niat pemerintah untuk menggeser konflik ke meja negosiasi. Sikap dan perilaku SBY sebagai pemimpin militer ini menjadi pembeda dalam resolusi konflik ini (Bağriyanik, 2016). Jika diamati dari sudut pandang perilaku, kepemimpinan politik sangat dipengaruhi latar belakangnya (Burns, 2010). Dengan latar belakang militer, otomatis Edy sejak dini dididik untuk berjiwa nasionalis dan membela negara. Didikan nasionalisme ini cenderung berbeda dibandingkan ketua umum yang berasal dari sipil. Oleh karena itu, ada kecenderungan Edy cenderung lebih dekat dengan pemerintah (Hanifan, 2016).

Intervensi tidak langsung ini dapat diamati dari poin-poin yang dititipkan Menpora untuk Edy. Menpora meminta Edy untuk menjalankan konsolidasi internal, dedikasi terhadap organisasi, melawan pengaturan skor, menemukan kebijakan untuk suporter, menjaga hubungan 


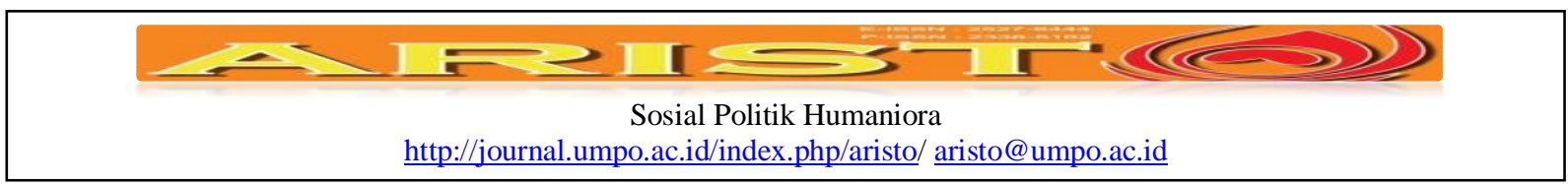

dengan pemerintah, mengembangkan sepak bola usia dini, mempersiapkan Asian Games 2018, membuka akuntabilitas keuangan, dan mendinginkan konflik. Jika diamati, jika Edy memperbaiki hubungan dengan pemerintah, maka pemerintah tetap dapat mengintervensi secara tidak langsung (Pandit Football, 2016). Intervensi ini terkait dengan kekuatan halus pemerintah (Alunaza\& Sanjaya, 2016).

Meskipun demikian, secara struktural, hanya Edy dipandang sebagai satu-satunya perwakilan pemerintah dalam struktur organisasi PSSI. Wakilnya dan seluruh bawahannya didominasi oleh kubu-kubu yang dekat dengan federasi disputan sebelumnya. Jadi, secara internal organisasi sekalipun, porsi intervensi pemerintah juga terbatas, hanya mengandalkan Edy (Hanifan, 2016). Pada tahun 2017, pemerintahan Joko Widodo memberikan perhatian khusus pada sepak bola. Presiden mengadakan rapat terbatas Percepatan Pembangunan Sepak bola Nasional dan melalui Menpora memaparkan program-program yang akan dijalankan, seperti infrastruktur, pembinaan, hingga keterbukaan komunikasi dengan PSSI. Dengan masuknya sepak bola nasional pada agenda negara, maka peran Edy dianggap vital (Tempo, 2017).

Tentara ditugaskan untuk menjaga integritas teritorial negara, menjaga dan mempromosikan kepentingan, dan sebagai simbol kenegaraan. Tentara juga ditugaskan untuk merespon ancaman luar maupun menjaga kepentingan dalam negeri. Peran tentara dijelaskan pada kondisi “something must be done". Tentara akan diturunkan jika pemerintah menyadari bahwa mereka lah satu-satunya yang bisa menyelesaikan suatu permasalahan. Tentara juga diminta menengahi konflik yang susah diselesaikan. Tentara memiliki kelebihan yaitu ketangkasan dalam segala kondisi. Tentara juga dapat menerjemahkan dan menjalankan penugasan langsung di lapangan. Tentara memiliki kedisiplinan yang jauh melebihi masyarakat sipil. Kekuatan memaksa adalah kelebihan tentara yang dapat digunakan untuk resolusi konflik (Bowen, 1998).

Intervensi tentara dalam sepak bola dapat dipelajari melalui kasus Argentina era 70-an. Dalam kondisi junta militer, militer yang saat itu memegang kendali pemerintahan, melakukan intervensi pada Piala Dunia 1978. Militer menghalalkan segala cara agar Argentina juara dunia, termasuk membayar pihak lawan agar mengalah. Meskipun diliputi kontroversi, pada tahun 1978 Argentina juara dunia untuk pertama kalinya (Archetti, 2005). 


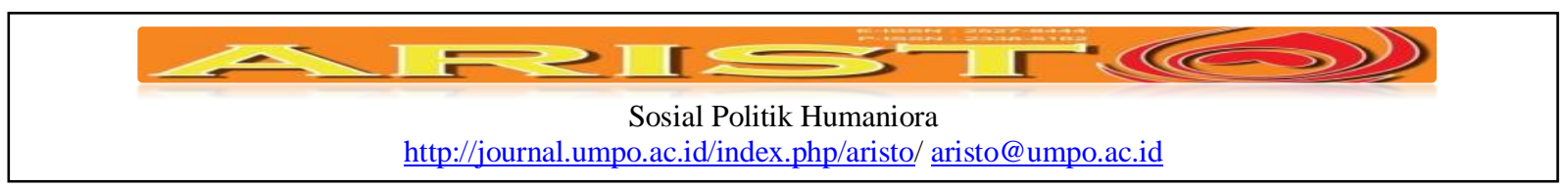

Meskipun dalam sejarah PSSI berkali-kali ditekan oleh FIFA, namun secara perilaku,

Edy Rahmayadi menunjukkan sikap yang konsisten. Edy sebagai tokoh militer menunjukkan kebijakan yang tegas. (Prayugi, 2017). Ketegasan ini dapat dikaitkan dengan gaya komunikasi efektif dan gaya komunikasi konteks rendah (low-context). Gaya komunikasi efektif dapat menarik simpati dari pengikut dengan beranekaragam karakter. Gaya komunikasi konteks rendah, dapat diartikan sebagai penglibatan pesan yang lugas dan tepat pada pokok permasalahan. Dengan gaya komunikasi ini, ada peluang bagi seorang pemimpin dapat diterima masyarakat (Lestarini, 2014).

Edy menerapkan kebijakan perubahan yang kontroversial yang bagi sebagian pihak dianggap sebagai wujud perlawanan dari Law of The Game dari FIFA. Edy merubah jumlah pergantian pemain dalam kompetisi dari tiga menjadi lima. Angka lima ini ditujukan untuk memfasilitasi perkembangan pemain muda, karena ada syarat wajib menurunkan tiga pemain muda minimal satu babak. Kebijakan lima pertandingan ini berbeda dengan aturan pertandingan resmi di negara-negara lain di bawah FIFA. Secara tegas, Edy memaksa FIFA harus menyetuji aturan tersebut. Padahal, peraturan penambahan pergantian pemain ini masih dalam tahap uji coba di beberapa turnamen oleh FIFA (Prayugi, 2017).

Dari pemberlakuan aturan pergantian pemain tersebut, dan pemberian tekanan terhadap FIFA, dapat diidentifikasikan bahwa Edy tidak lain adalah penyalur kepentingan pemerintah. Pemerintah sadar bahwa induk PSSI adalah FIFA.Namun, FIFA harus disadarkan bahwa PSSI beroperasi di Indonesia (Hanifan, 2016).

\section{Konsekuensi Negatif Penglibatan Figur Politk}

Meskipun tergolong berhasil menjadi kepanjangan tangan pemerintah dalam resolusi konflik PSSI, tata kelola sepak bola melibatkan figur politik memiliki kekurangan. Pertama, Edy menentang proses perpindahan dua pemain Indonesia ke Malaysia, yaitu Evan Dimas dan Ilham Udin Armaiyn. Proses perpindahan dua pemain itu dikritik karena bersamaan dengan persiapan tim nasional dalam Asian Games 2018. Target Edy pada kejuaraan tersebut sangat tinggi, yaitu semifinal. Di sisi lain, pemerintah melalui Menpora Imam Nahrawi tidak sepakat dengan kebijakan tersebut (Ridwan, 2017).

Kebijakan kontroversial Edy ini disebabkan keinginan figur politik tersebut untuk memperoleh visibilitas dalam ruang publik. Prestasi timnas di level regional akan berdampak 


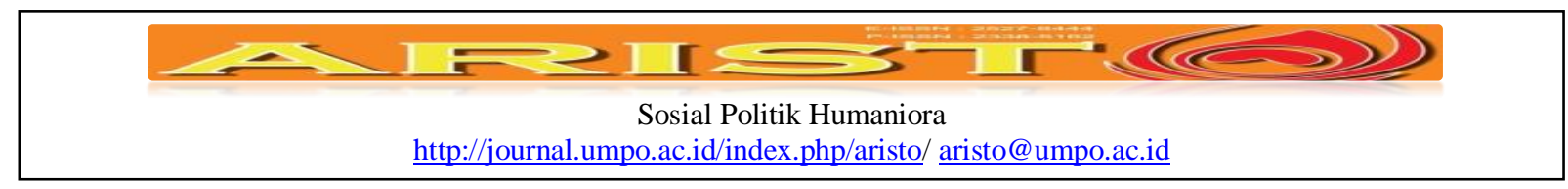

besar kepada figur politik tersebut. Figur politik tersebut ingin menjadi pusat perhatian masyarakat Indonesia, meskipun dengan cara-cara yang kontroversial. Selain itu, Edy berkeinginan menunjukkan sikapnya kepada publik. Sebagai tentara, Edy seharusnya memiliki sikap tegas dan nasionalis. Oleh karena itu, Edy mengkomunikasikan pesan-pesan kepada media massa untuk memposisikan diri pada kedua sikap (Iqbal, 2016).

Kedua, Edy pada perjalanannya menunjukkan ambisinya sebagai figur politik. Pada Agustus 2017, Edy mendeklarasikan diri berniat menjadi cagub Sumatera Utara. Kondisi pencalonan ini memverifikasi argumen Colombijn bahwa sepak bola Indonesia tidak jauh dari politik. Selain itu, sepak bola Indonesia juga digunakan sebagai alat untuk menjadi kepala daerah. Jika Edy berhasil terpilih menjadi Gubernur Sumatera Utara, maka ada kemungkinan Edy rangkap jabatan sebagai Pangkostrad, Ketua Umum PSSI, dan Gubernur Sumatera Utara. Pada dasarnya, seorang Pangkostrad dilarang rangkap jabatan dengan kepala daerah. Hal ini juga berusaha tidak digubris oleh Edy (Fajriyah, 2017; Wiratri, 2017).

Melihat kondisi ini, PSSI melalui sekjennya Ratu Tisha Destria, tidak menentang ambisi ketua umumnya. Tisha menganggap bahwa hal tersebut sebagai urusan politik pribadi Edy, seharusnya tidak disangkutpautkan dengan masa depan federasi. Pada satu sisi, pemerintah tidak dapat mengatur sepenuhnya ketua umum militer tersebut. Meskipun demikian, pemerintah berhasil memanfaatkan figur politik untuk menjalankan tata kelola sepak bola (Wiratri, 2017).

Sepakbola Indonesia hanya menjadi ruang publik bagi figur politik didalamnya. Edy Rahmayadi memverifikasi tren tersebut. Edy menjadi ketum PSSI demi memperoleh visibilitas dalam ruang publik penting seperti sepak bola. Edy mengkomunikasi pesan-pesan politik dalam setiap aksinya di ruang publik. Kemudian, Edy memanfaatkan ruang publik untuk mewujudkan visi politiknya memperoleh jabatan eksekutif dalam pemerintahan.

\section{Kesimpulan}

Dari paparan dalam artikel ini, dapat disimpulkan beberapa hal. Pertama, tata kelola olahraga di Indonesia menggunakan figur politik. Berbeda dengan beberapa kasus di negara lain, konflik politik mengharuskan tata kelola olahraga yang juga melibatkan aspek politik. Dominasi FIFA menjadi alasan lain perlunya tata kelola olahraga di Indonesia memerlukan figur politik. Pemerintah Indonesia tidak dapat secara langsung mempengaruhi sepak bola, hal tersebut sesuai dengan implementasi konsep governance. Kedua, tata kelola olahraga di Indonesia memerlukan 


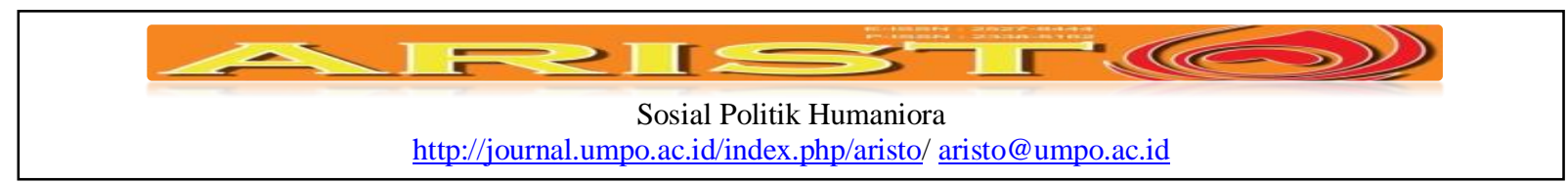

figur tentara sebagai ketua federasi. Tentara adalah kepanjangan tangan dari pemerintah untuk mengamankan kepentingan negara sekaligus berpengalaman dalam menyelesaikan konflik. Kekuatan pemaksaan yang dimiliki figur dari kalangan militer diharapkan dapat menghentikan para disputan untuk semakin memperkeruh konflik. Dengan peran ketua umum dari militer, konflik berhasil diselesaikan. Ketua umum memiliki ketegasan untuk melakukan perubahan internal sepak bola nasional. Ketiga, ada hal yang tidak berubah dalam sepak bola Indonesia. Sepak bola selalu digunakan sebagai kendaraan politik bagi politisi. Dengan segala kelebihan seorang tentara dalam resolusi konflik, ambisi politik pribadi tetap ada, khususnya di Indonesia. Figur politik memanfaatkan sepak bola untuk mendominasi ruang publik dan memperoleh visibilitas. Citra positif dalam sepak bola (disebabkan prestasi) diusahakan oleh figur politik sekalipun itu menggunakan cara kontroversial. Imej positif yang berhasil dihimpun figur politik pada selanjutnya digunakan untuk mengikuti pemilu kepala daerah. Penelitian ini hanya memfokuskan pada kasus penglibatan figur politik dalam tata kelola olahraga, khususnya sepak bola. Penelitian mendatang dapat ditujukan pada kepemimpinan dan gaya komunikasi figur politik dalam sepak bola (Lestarini, 2014). Selain itu, penggunaan media baru untuk tata kelola sepak bola, yang merupakan produk dari perkembangan teknologi informasi dan komunikasi (TIK), dapat dijadikan sebagai fokus penelitian mendatang. Misalnya adalah implementasi konsep "smart city" (kota pintar) pada konteks sepak bola. Konsep kota pintar digunakan oleh pemerintah sebagai solusi dari permasalahan urban. Sejarah sepak bola Indonesia diliputi konflik, oleh karena itu, penggunaan TIK dapat menjadi urgensi sebagai solusi sekaligus sarana pembangunan sepak bola (Sanjaya et al, 2017). 


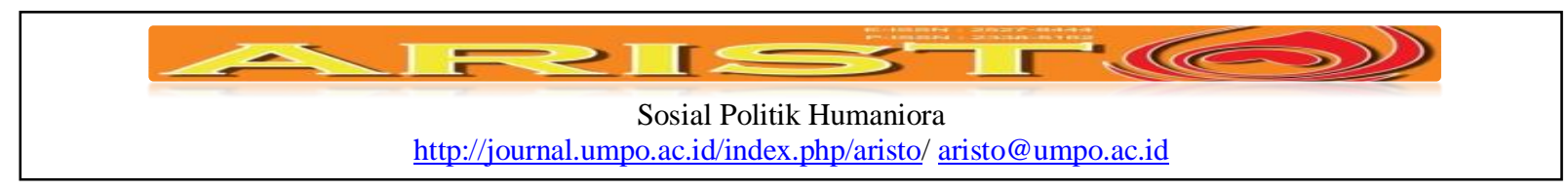

\section{Daftar Pustaka}

Alunaza, H, \& Sanjaya, A.. (2016) Aktualisasi Soft Diplomacy Indonesia Melalui Tari Saman Gayo dalam Promosi Perdamaian Dunia dan Penguatan Identitas Lokal: Analisa Pasca Pengakuan Tari Samanoleh UNESCO. Dalam Proceeding of The 1 st International Conference on Social Sciences and Humanities (ICSSH), LIPI, Jakarta, Indonesia, 135148.

Amara, M., Henry, I., Liang, J., \& Uchiumi, K. (2005). The governance of professional soccer: Five case studies-Algeria, China, England, France and Japan. European Journal of Sport Science, 5(4), 189-206.

Anggoro, A.D.. (2014). Media, Politik dan Kekuasaan: Analisis Framing Model Robert N. Entman tentang Pemberitaan Hasil Pemilihan Presiden, 9 Juli 2014 di TV One dan Metro TV. Aristo, 2(2), 25-52.

Archetti, E. P. (2005). Military Nationalism, Football Essentialism, and Moral Ambivalence. Dalam A. Tomlinson \& C. Young (Eds.), National Identity and Global Sports Events. New York: State University of New York Press, New York.

Ariyanto, K. (2014). Analyzing the Conflict between Football Organizations in Indonesia. Procedia-Social and Behavioral Sciences, 115, 430-435.

Aruan, H. B. P., Sirait, N. N., \& Leviza, J. (2014). Berlakunya Statuta Fédération Internationale de Football Association (FIFA) Dikaitkan dengan Kedaulatan Negara (Studi Kasus Dualisme Persatuan Sepakbola Seluruh Indonesia (PSSI)). Journal of International Law, 2(1).

Bang, S.Y. 2012. Investigation of Institutional Discourse on Change in South Korean Football from 1945 to Pre-2002 FIFA World Cup. PhD thesis. Loughborough University.

Boue, K. \& Kjaer, K.. 2010. Creating Value through Strategic Partnerships between Businesses and NGOs. Master thesis. Copenhagen Business School.

Bowen, D. (2000). Something Must be Done-Military Intervention. Studies in Conflict and Terrorism, 23(1), 1-19.

Burns, J.M. (2010). Leadership. New York: Harper Collins.

Christian, A. (2015). Begini Kronologi Kisruh PSSI dan Menpora. Diakses 4 Agustus 2017 dariTribunnews: http://kaltim.tribunnews.com/2015/05/26/begini-kronologi-kisruh-pssidan-menpora?page $=2$

Colombijn, F. (2000). The politics of Indonesian football. Archipel, 59(1), 171-200. 


Sosial Politik Humaniora
http://journal.umpo.ac.id/index.php/aristo/ aristo@umpo.ac.id

Dorsey, JM \& Sebastian, LC. (2015). The Politics of Indonesian and Turkish Soccer: Analysis The Politics of Indonesian and Turkish Soccer: a Comparative Analysis. Dalam: Cho Y (Eds.), Football in Asia: History, Culture and Business. New York: Routledge.

Fajriyah, T. (2017).Ketum PSSI: Tak Masalah Rangkap Jabatan Gubernur Sumut.Diakses 4 Agustus 2017 dariCNN Indonesia: https://www.cnnindonesia.com/olahraga/20170803203008-142-232350/ketum-pssi-takmasalah-rangkap-jabatan-gubernur-sumut/

Hanifan. (2016).Tarik Menarik Siapa Mengontrol Edy Rahmayadi di PSSI? Diakses 4 Agustus 2017 dari Tirto.id: https://tirto.id/tarik-menarik-siapa-mengontrol-edy-rahmayadi-dipssi-b36g

Iqbal, M. (2016). Ridwan Kamil for mayor: A study of political figures on twitter. Unpublished master's thesis. Stockholm University, Swedia

Lestarini, N.. (2014). Gaya Komunikasi Calon Kepala Desa dalam Pemilihan Kepala Desa Tahun 2013: Penelitian Pada Pemilihan Kepala Desa di Desa Nglumpamg Kecamatan Mlarak Kabupaten Ponorogo. Aristo, 2(2), 1-14.

Meier, H. E., \& Garcia, B. (2015). Protecting Private Transnational Authority against Public Intervention: FIFA's Power over National Governments. Public Administration, 93(4), 890-906.

Nasution, R.D.. (2005). Indonesia sebagai Emerging Power: Perspektif Ekonomi Militer. Aristo,3(2), 54-67.

Panditfootball. (2017). Sepenggal Kisah Edy Rahmayadi, Ketua Umum Baru PSSI, Diakses 4 Agustus 2017 dari Panditfootball: http://panditfootball.com/cerita/206675/RDK/161111/sepenggal-kisah-edy-rahmayadiketua-umum-baru-pss

Prayugi, W. (2017). PSSI Segera Komunikasi dengan FIFA soal Regulasi Liga 1. Diakses 4 Agustus 2017 dari Bola.com: http://www.bola.com/indonesia/read/2905139/pssisegera-komunikasi-dengan-fifa-soal-regulasi-liga-1

Priyasidarta, D. 2017. Pilgub Jatim, La Nyalla Klaim Didukung Gerindra, PAN, dan PKS. Diakses 2Januari 2018 dari Tempo.co:https://nasional.tempo.co/read/1028759/pilgubjatim-la-nyalla-klaim-didukung-gerindra-pan-dan-pks

Ridwan, M. 2017. Anomali Sikap Edy Rahmayadi Terhadap Pemain Indonesia Ke Luar Negeri. Diakses 2 Januari 2018 dari goal.com: http://www.goal.com/id/berita/anomali-sikapedy-rahmayadi-terhadap-pemain-indonesia-ke/de6yrpjh4daf18f0ylseo28cr 


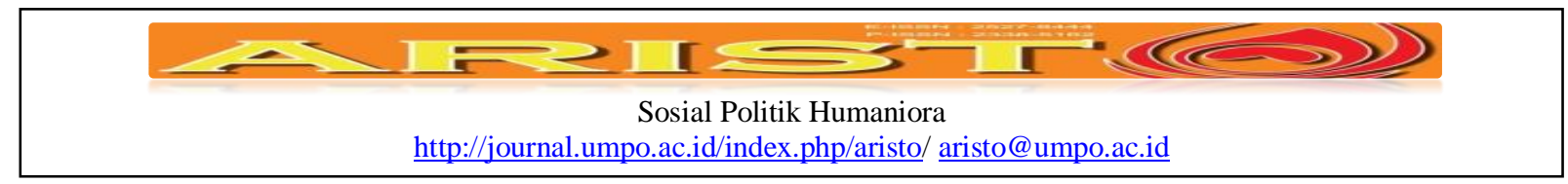

Sammy, A. (2012). Inilah Kronologi Lengkap Perseteruan PSSI dan KPSI.Diakses 4 Agustus 2017 dari Republika: http://www.republika.co.id/berita/sepakbola/ligaindonesia/12/03/19/m14r3z-inilah-kronologi-lengkap-perseteruan-pssi-dan-kps

Sanjaya, A., Alunaza, H., Hidayah, T., Biyoga, S. (2017). Mass Media and Green Airport in Indonesia: Do They Aware of Smart Village? Dalam Proceedings of The 9 th International Graduate Students and Scholars' Conference in Indonesia (IGSSCI), UGM Yogyakarta, Yogyakarta, Indonesia, 543-552.

Santama, J. 2017. Mantan Ketum PSSI Djohar Arifin Maju Pilbup Langkat Via Independen. Diakses 2 Januari 2018 dari Detik.com:https://news.detik.com/berita/d3751325/mantan-ketum-pssi-djohar-arifin-maju-pilbup-langkat-via-independen

Santosa, G. A. (2017). China's Soft Power: The Making of Football Superpower: 'Soft Power'Cina: Menuju Kekuatan Adidaya dalam Sepakbola. Jurnal Pertahanan \& Bela Negara, 7(1).

Susanto, H. (2016). Sejarah Hari Ini (30 Mei): FIFA Resmi Jatuhkan Sanksi Untuk Indonesia. Diakses 4 Agustus 2017 dari goal.com: http://www.goal.com/id-ID/news/5650/sejarahhari-ini/2016/05/30/24069092/sejarah-hari-ini-30-mei-fifa-resmi-jatuhkan-sanksi-untuk

Sugiyono. (2011). Metode Penelitian Kuantitatif Kualitatif dan $R \&$ \& Bandung : Alfabeta.

Tempo. 2017. Program Menpora Seusai Ikuti Rapat Kabinet Soal Sepak Bola.Diakses 2 Januari 2018 dari Tempo.co: https://bola.tempo.co/read/news/2017/01/25/099839456/programmenpora-seusai-ikuti-rapat-kabinet-soal-sepak-bola

Wiratri, L. 2017. Edy Rahmayadi Daftar Jadi Cagub Sumatera Utara, Pengurus PSSI Buka Suara. Diakses 4 Agustus 2017 dari Indosport: http://www.indosport.com/sepakbola/20170802/edy-rahmayadi-daftar-jadi-cagubsumut-ini-respons-pssi

Wirabhuana, K. 2017. Nurdin Halid Tidak Main-Main Maju Jadi Cagub Sulsel. Diakses 2 Januari 2018 dari kumparan.com:https://kumparan.com/golkar-celebes/nurdin-halidtidak-main-main-maju-jadi-cagub-sulsel\#gTmocCmfQ14t1IQY.99 